\title{
Molecular characterization of virulence factors in Staphylococcus aureus isolated from bovine subclinical mastitis in central Ethiopia
}

Desiye Tesfaye Tegegne ${ }^{1 *}$, Gezahegne Mamo², Hika Waktole ${ }^{2}$ and Yohannes Equar Messele ${ }^{1}$

\begin{abstract}
Purpose: Staphylococcus aureus (S. aureus) is the most important pathogen involved in bovine mastitis in dairy production. S. aureus produces a spectrum of extracellular protein toxins and virulence factors which are thought to contribute to the pathogenicity of the organism. The aim of this work was to isolate and molecular characterize $S$. aureus associated with bovine subclinical mastitis in the central part of Ethiopia.

Methods: A total of 265 lactating dairy cows from various dairy farms in four different geographical locations were screened by the California mastitis test (CMT) for bovine subclinical mastitis. One hundred thirty CMT-positive milk samples were collected and transported to the laboratory. Different biochemical tests and polymerase chain reaction (PCR) were used for the identification of $S$. aureus isolates. Finally, PCR was performed for molecular detection of virulence genes.

Results: From a total of 265 lactating dairy cows screened, 49\% $(n=130)$ were positive for bovine subclinical mastitis. One hundred thirty mastitic milk samples were subjected to bacterial culturing, and one hundred (76\%) $\mathrm{S}$. aureus isolates were identified based on phenotypic characters. Sixty-eight confirmed S. aureus isolates were obtained using PCR. The confirmed S. aureus isolates were tested for six virulence genes (tsst-1, hlb, eta, sea, clfA, and icaD) using PCR. Of the six virulence genes screened from all the isolates, only two (clfA and eta) were detected in the isolates. Out of 68 isolates, $25 \%$ and 22\% were possessed the eta and clfA genes, respectively.

Conclusion: The presence of Staphylococcus aureus having virulence genes (eta and clfA) revealed that mastitis is a major concern nowadays affecting animal health, milk quality, and yield. Further genomic study of these isolates will provide broad new insights on virulence.
\end{abstract}

Keywords: Bovine, Staphylococcus aureus, Subclinical mastitis, Virulence genes

* Correspondence: desiye.tegegne@gmail.com

${ }^{1}$ Animal Biotechnology Research Program, National Agricultural

Biotechnology Research Center, Ethiopian Institute of Agricultural Research,

P.O. Box: 249, Holeta, Ethiopia

Full list of author information is available at the end of the article

(c) The Author(s). 2021 Open Access This article is licensed under a Creative Commons Attribution 4.0 International License, which permits use, sharing, adaptation, distribution and reproduction in any medium or format, as long as you give appropriate credit to the original author(s) and the source, provide a link to the Creative Commons licence, and indicate if changes were made. The images or other third party material in this article are included in the article's Creative Commons licence, unless indicated otherwise in a credit line to the material. If material is not included in the article's Creative Commons licence and your intended use is not permitted by statutory regulation or exceeds the permitted use, you will need to obtain permission directly from the copyright holder. To view a copy of this licence, visit http://creativecommons.org/licenses/by/4.0/. 


\section{Background}

Mastitis is considered to be the most frequent and most costly production disease in dairy herds of developed and developing countries including Ethiopia. Mastitis is an inflammatory response of the teat canal as a result of bacterial infection (Song et al., 2020). Staphylococcus aureus (S. aureus) is one of the most recognized pathogens causing many serious diseases in humans and animals worldwide and is the most common causative agent of clinical and subclinical bovine mastitis (Ote et al., 2011).

Mastitis caused by $S$. aureus is the result of the production of several virulence factors that can contribute in different ways of pathogenesis (Vaughn et al., 2020). Virulence factors of $S$. aureus can be grouped broadly into two major classes which include surface localized structural components that serve as virulence factors and secreted virulence factors, which together help this pathogen to evade the host's defenses and colonize mammary glands (Diep and Otto, 2008). Some of the surface localized structural components that serve as virulence factors include membrane-bound factors (collagen binding protein, fibrinogen binding protein, elastin binding protein, and penicillin binding protein ), cell wall-bound factors (protein A, $\beta$-Lactamase, and protease), and cell surface-associated factors (capsule and slime) (Diep and Otto, 2008). Some of the known secretory virulence factors are toxins (staphylococcal enterotoxins, toxic shock syndrome toxin 1, hemolysins, and exfoliatin) and enzymes (coagulase, staphylokinase, DNAase, phosphatase, lipase, and phospholipase). In addition to specific virulence factor, $S$. aureus also possesses different mechanisms or traits such as biofilm formation, adhesion to and invasion into mammary epithelial cells, and formation of small colony variant $(\mathrm{SCV})$ that enables this pathogen to resist host defense mechanisms. Some of these toxins are known to function as superantigens that cause increased immunological reactivity in the host (Rollin et al., 2015; Bobbo et al., 2017).

The differences in pathogenicity of S. aureus strains could result from geographical distribution and from host- and tissue-related characteristics (van Leeuwen et al., 2005). The numbers and combination of virulence genes may be important contributions to the pathogenic potential of S. aureus strains (Zecconi et al., 2006). A high number of $S$. aureus genotypes present in bovine herds worldwide has been studied to develop better strategies of treating mastitis (Kot et al., 2016). The identification and characterization of virulence factors of S. aureus causing bovine mastitis will enhance our understanding of the pathogenesis of intramammary infection (Zecconi et al., 2006). In addition, the antibiogram of $S$. aureus needs to be studied which would indicate the pattern of resistance to various antibacterials contributing to their virulence properties (Graveland et al., 2011). These may in turn contribute to the development of methods to minimize the production losses due to mastitis. Further, the study of the evolution of strain-specific transmission and virulence characteristics including antibiotic resistance in S. aureus isolated from bovine mastitis may help us to understand mechanisms behind the emergence of new strains or shifts in mastitis epidemiology in response to control measures, including antibiotic treatment and vaccination (Yu et al., 2012).

However, at present, few reports have been reported about the occurrence of virulence factors among $S$. aureus isolated from milk of cows suffering from mastitis but not identified by molecular technique in the central part of Ethiopia. Furthermore, there is a literature dearth on the prevalence and genetic characterization of virulence determinants in S. aureus in Ethiopia. As to our knowledge, most of the researches in Ethiopia were done in association with the prevalence of bovine mastitis cases and its associated risk factors (Abera et al., 2010; Tesfaye et al., 2010) but molecular data on $S$. aureus causing bovine mastitis in remain scarce. Therefore, the aim of this study was to determine the prevalence of $S$. aureus isolates associated with bovine subclinical mastitis and the prevalence of virulence genes in those isolates in central parts of Ethiopia.

\section{Methods}

\section{Samples and study population}

Two hundred and sixty-five milk samples were collected from lactating dairy cows that showed subclinical mastitis symptoms. Milk samples were collected from intensive production system across different geographical locations (Adaberga, Ambo, Bishoftu, and Holeta) in the central part of Ethiopia since November 2018 to June 2019. Milk samples were collected and proceeded as described in the previous study (Patel et al., 2017). Briefly, udders were wiped with $70 \%$ ethyl alcohol and few drops of milk were discarded initially. Simultaneously, CMT was executed on the site, and on the basis of the CMT score, samples were collected (Bhatt et al., 2011; Patel et al., 2017). The study areas were purposively selected based on the agro-ecological differences and abundance of dairy farm milk sheds. The farms included in this study were involved in the production of milk for selfconsumption and supplier to milk cooperative.

\section{Bacterial isolation and identification}

Milk samples were evaluated for mastitis-causing bacteria by bacteriological culture and biochemical tests following the National Mastitis Council Guidelines (Oliver et al., 2004). Briefly, $100 \mu$ l of milk sample was inoculated onto nutrient broth media (Merck, Germany) with 5\% sheep blood (Becton Dickinson Microbiology System, Cockeysville) and incubated at $37^{\circ} \mathrm{C}$ for $24 \mathrm{~h}$. 
Plates were evaluated for bacterial growth, colony morphology, and hemolysis after $24 \mathrm{~h}$. Each pure colony was identified by Gram-stain, followed by a catalase test. Catalase-positive cocci were considered Staphylococcus species and further confirmed by polymerase chain reaction (PCR) and tube coagulase test using rabbit plasma (NVI, Bishoftu, Ethiopia) to differentiate S. aureus from coagulase-negative Staphylococcus species. The resulting culture was used for bacterial DNA extraction, and the remaining overnight culture of S. aureus isolate in tryptic soy broth (TSB) (BHI, Merck, Germany) was mixed with an equal volume of sterile $85 \%$ glycerol and stored in a $-80^{\circ} \mathrm{C}$ freezer for further molecular work.

\section{Bacterial DNA extraction}

Staphylococcus aureus bacteria were sub-cultured on nutrient broth media (NB, Merck, Germany) and incubated at $37^{\circ} \mathrm{C}$ for $24 \mathrm{~h}$. Genomic DNA of all phenotypically positive $S$. aureus isolates was extracted from the culture using the Zymo Research Fungal and Bacterial Genomic DNA MiniPrepTM kit (Zymo Research, Irvine, USA) following the manufacturer's instructions. Purity, quality, and quantity of extracted DNA were measured using a Nanodrop device (NanoDrop, Thermo Scientific, USA), gel electrophoresis, and spectrophotometer. The extracted genomic DNA was stored at $-20^{\circ} \mathrm{C}$ until the next use.

\section{Molecular confirmation of S. aureus, detection of virulence, and methicillin-resistant genes}

Polymerase chain reaction (PCR) was used to amplify the 16SrRNA gene fragment of S. aureus isolates according to the previously described protocol [17] using
EdvoCycler $^{\text {Tw }}$ PCR machine (Edvotek, Inc, Bethesda). Also, all isolates were tested by PCR for the presence of the staphylococcal enterotoxin A (sea), exfoliative toxin A (eta), beta hemolysin toxin ( $h l b)$, clamping factor A (clfa), intercellular adhesion D (icaD), toxic shock syndrome toxin-1 (tsst-1), and methicillin-resistant genes according to the previously described protocol [18-21]. Primers used for the PCR amplification were synthesized by Sigma-Aldrich (Bonn, Germany) and master mix synthesized by BioBasic company (BioBasic, Canada). The primers used for molecular identification of different virulence-associated genes are indicated in Table 1 . Lyophilized primers for the target genes were reconstituted using DNase-RNase-free sterile water to obtain $1000 \mu \mathrm{M}$ stock solutions. All primers were stored at $-20^{\circ} \mathrm{C}$ and then finally diluted to a working concentration of $10 \mu \mathrm{M}$. PCR was carried out in a total volume of $25 \mu \mathrm{l}$ containing $12.5 \mu \mathrm{l}$ of $1 \mathrm{X}$ Taq PCR Master Mix (Bio Basic, Canada), $1 \mu \mathrm{l}$ of the forward primer and $1 \mu \mathrm{l}$ of the reverse primer, $3 \mu \mathrm{l}$ of DNA template, and $7.5 \mu \mathrm{l}$ sterile nuclease-free water. The cyclic polymerase chain reaction conditions of the different primer sets are described in Table 2. PCR products were run on a $1 \%$ agarose $(\mathrm{w} / \mathrm{v})$ gel using electrophoresis, stained with gel red (Merck, Darmstadt, Germany) at 120 volts for $1 \mathrm{~h}$, and visualized under UV light using a BioDoc-itTM imaging system (Cambridge, UK). We used GeneRuler 100 bp Plus DNA Ladder (Bioneer).

\section{Statistical analysis}

The data generated from the study was arranged, coded, and entered into an Excel spreadsheet (Microsoft ${ }^{\circ}$ Office Excels 2010) and subjected to statistical analysis. The

Table 1 Description of the primers used for molecular identification of different virulence-associated gene detection in S. aureus isolates

\begin{tabular}{|c|c|c|c|}
\hline Target gene & Primer name and its sequence $\left(5^{\prime} \rightarrow 3^{\prime}\right)$ & Amplicon size (in bp) & Reference \\
\hline mecA & $\begin{array}{l}\text { MECA_F: GGCTATCGTGTCACAATCGTT } \\
\text { MECA_R: TCACCTTGTCCGTAACCTGA }\end{array}$ & 689 & Melo et al. (2014) \\
\hline $\begin{array}{l}\text { 16SrRNA } \\
\text { Staph. aureus specific }\end{array}$ & $\begin{array}{l}\text { Sau234_F: CGATTCCCTTAGTAGCGGCG } \\
\text { Sau1501_R: CCAATCGCACGCTTCGCCTA }\end{array}$ & 1267 & Riffon et al. (2001) \\
\hline sea & $\begin{array}{l}\text { SEA_F: TTGGAAACGGTTAAAACGAA } \\
\text { SEA_R: GAACCTTCCCATCAAAAACA }\end{array}$ & 120 & Mehrotra et al. (2000) \\
\hline tsst-1 & $\begin{array}{l}\text { TSST_F: ATGGCAGCATCAGCTTGATA } \\
\text { TSST_R: TITCCAATAACCACCCGTIT }\end{array}$ & 350 & Mehrotra et al. (2000) \\
\hline eta & $\begin{array}{l}\text { ETA_F: CGCTGCGGACATTCCTACATGG } \\
\text { ETA_R: TACATGCCCGCCACTTGCTTGT }\end{array}$ & 676 & Li et al. (2018a) \\
\hline$h / b$ & $\begin{array}{l}\text { HLB_F: GTGCACTTACTGACAATAGTGC } \\
\text { HLB_R: GTTGATGAGTAGCTACCTTCAGT }\end{array}$ & 309 & Li et al. (2018a) \\
\hline ClfA & $\begin{array}{l}\text { CLFA_F: GCAAAATCCAGCACAACAGGAAACGA } \\
\text { CLFA_R: CTTGATCTCCAGCCATAATTG GTGG }\end{array}$ & 638 & Kumar et al. (2009) \\
\hline$i c a D$ & $\begin{array}{l}\text { ICAD_F: AAGCCAGACAGAGGCAATATCCA } \\
\text { ICAD_R: AGTACAAACAAACTCATCCATCCGA }\end{array}$ & 249 & Greco et al. (2008) \\
\hline
\end{tabular}

NB: Sea staphylococcal enterotoxin a, tsst-1 toxic shock syndrome toxin one, eta exfoliative toxin A, hlb beta hemolysin toxin, clfA clumping factor A, icaD intracellular adhesive toxin, mecA methicillin resistance 
Table 2 Cyclic polymerase chain reaction conditions of the different primer sets

\begin{tabular}{|c|c|c|c|c|c|}
\hline \multirow[t]{2}{*}{ Target genes } & \multirow{2}{*}{$\begin{array}{l}\text { Initial } \\
\text { denaturation }\end{array}$} & \multicolumn{3}{|c|}{ Amplification (35 cycles) } & \multirow{2}{*}{$\begin{array}{l}\text { Final } \\
\text { extension }\end{array}$} \\
\hline & & Denaturation & Annealing & Extension & \\
\hline mecA & $94^{\circ} \mathrm{C} / 1.5 \mathrm{~min}$ & $95^{\circ} \mathrm{C}$ for $45 \mathrm{~s}$ & $55^{\circ} \mathrm{C}$ for $1 \mathrm{~min}$ & $72^{\circ} \mathrm{C} / 45 \mathrm{~s}$ & $72^{\circ} \mathrm{C} / 10 \mathrm{~min}$ \\
\hline $\begin{array}{l}\text { 16SrRNA } \\
\text { S. aureus specific }\end{array}$ & $94^{\circ} \mathrm{C} / 5 \mathrm{~min}$ & $94^{\circ} \mathrm{C} / 30 \mathrm{~s}$ & $55^{\circ} \mathrm{C} / 30 \mathrm{~s}$ & $72^{\circ} \mathrm{C} / 45 \mathrm{~s}$ & $72^{\circ} \mathrm{C} / 5 \mathrm{~min}$ \\
\hline sea & $95^{\circ} \mathrm{C} / 10 \mathrm{~min}$ & $94^{\circ} \mathrm{C} / 2 \mathrm{~min}$ & $55^{\circ} \mathrm{C} / 2 \mathrm{~min}$ & $72^{\circ} \mathrm{C} / 1 \mathrm{~min}$ & $72^{\circ} \mathrm{C} / 1 \mathrm{~min}$ \\
\hline tsst-1 & $95^{\circ} \mathrm{C} / 10 \mathrm{~min}$ & $94^{\circ} \mathrm{C} / 2 \mathrm{~min}$ & $55^{\circ} \mathrm{C} / 2 \mathrm{~min}$ & $72^{\circ} \mathrm{C} / 1 \mathrm{~min}$ & $72^{\circ} \mathrm{C} / 1 \mathrm{~min}$ \\
\hline eta & $94^{\circ} \mathrm{C} / 5 \mathrm{~min}$ & $94^{\circ} \mathrm{C} / 30 \mathrm{~s}$ & $57^{\circ} \mathrm{C} / 30 \mathrm{~s}$ & $72^{\circ} \mathrm{C} / 45 \mathrm{~s}$ & $72^{\circ} \mathrm{C} / 10 \mathrm{~min}$ \\
\hline$h / b$ & $94^{\circ} \mathrm{C} / 5 \mathrm{~min}$ & $94^{\circ} \mathrm{C} / 30 \mathrm{~s}$ & $58^{\circ} \mathrm{C} / 30 \mathrm{~s}$ & $72^{\circ} \mathrm{C} / 20 \mathrm{~s}$ & $72^{\circ} \mathrm{C} / 10 \mathrm{~min}$ \\
\hline clfA & $94^{\circ} \mathrm{C} / 10 \mathrm{~min}$ & $94^{\circ} \mathrm{C} / 10 \mathrm{~min}$ & $55^{\circ} \mathrm{C} / 1 \mathrm{~min}$ & $72^{\circ} \mathrm{C} / 1 \mathrm{~min}$ & $72^{\circ} \mathrm{C} / 10 \mathrm{~min}$ \\
\hline$i c a D$ & $94^{\circ} \mathrm{C} / 10 \mathrm{~min}$ & $94^{\circ} \mathrm{C} / 30 \mathrm{~s}$ & $53^{\circ} \mathrm{C} / 30 \mathrm{~s}$ & $72^{\circ} \mathrm{C} / 30 \mathrm{~s}$ & $72^{\circ} \mathrm{C} / 10 \mathrm{~min}$ \\
\hline
\end{tabular}

prevalence to every test was calculated as the number of positive cattle divided by the number of examined cases within the specified period. The Pearson chi-square test $\left(x^{2}\right)$ was applied to determine the existence of any association between sampling areas and virulence-associated genes using SPSS software version 22.0.

The significance level was set at $P$-value $(0.05)$ and 95\% confidence level. In all cases, 95\% confidence level and $p$-value less than 0.05 were considered statistical significance.

\section{Results}

\section{Isolation and identification of S. aureus isolates}

In this study, of the 265 lactating dairy cows screened, 130 (49\%) were positive for bovine mastitis based on CMT. One hundred and thirty mastitic milk samples were subjected to bacterial culturing, and 100 (76\%) S. aureus isolates were identified based on the morphological and biochemical characters. From a total of 100 phenotypically positive S. aureus isolates, 68 (68\%) of them were confirmed $S$. aureus isolates through PCR amplification. The presence of $16 \operatorname{SrRNA}$ gene (1267 bp) was confirmed by PCR in S. aureus-positive isolates (Fig. 1).

\section{Prevalence of virulence genes in S. aureus}

All 68 PCR-confirmed $S$. aureus isolates were tested for six virulence genes including tsst-1, hlb, eta, sea, clfA, and icaD using PCR amplification. Of the six virulence genes screened from all the isolates, only two (clfA and eta) were detected (Fig. 2). The isolates for the current study were obtained from mastitic bovine milk samples representing four geographical locations (Adaberga, Ambo, Bishoftu, and Holeta) in the central parts of Ethiopia. Out of 68 isolates, 17 (25\%), 15 (22\%), and 6 (8.8\%) isolates possessed eta, clfA, and a combination of eta and clfA genes, respectively. The large proportion of these isolates which harbor eta and clfA genes were obtained from Holeta $(46 \%, 7 / 15)$ and Adaberga $(52 \%, 9 / 17)$, respectively. The prevalence of virulence genes was not statistically significant between different sampling areas $\left(X^{2}=1.239 ; P=0.744\right)$. The prevalence rates of the virulence genes are depicted in Fig. 3. The expected PCR

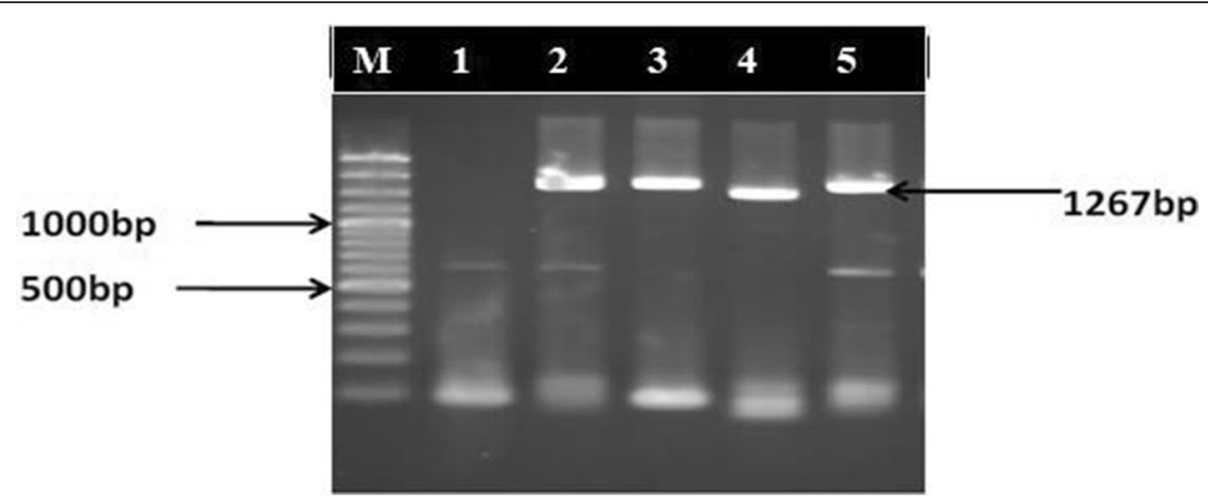

Fig. 1 Amplicons of the 16Sr RNA gene of representative S. aureus with a size of $1267 \mathrm{bp}$. Lane M is a 100-bp plus DNA marker (DNA ladder, BioBasic); lanes 1 to 5 are test samples 


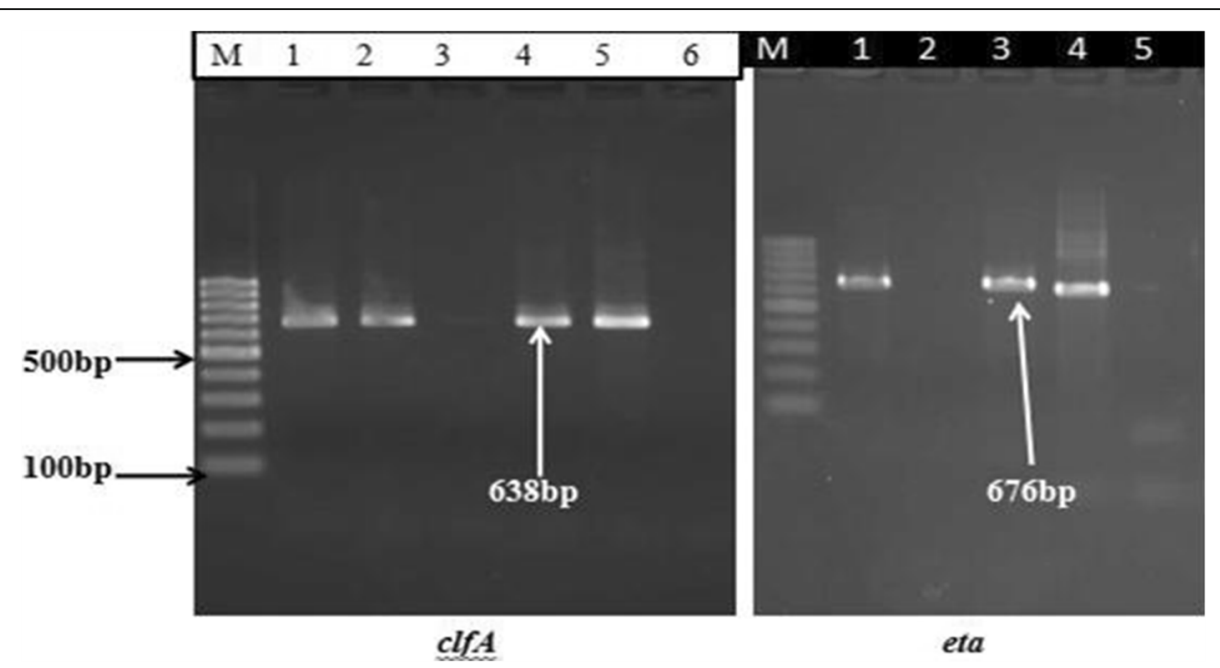

Fig. 2 Agarose gel electrophoresis of $P C R$ amplicon of clfA and eta genes of representative S. aureus isolates. Lane M is a 1000-bp DNA marker (DNA ladder, Bio Basic); lanes 1 to 6 are test samples

product sizes obtained from these PCR products were 638 and $676 \mathrm{bp}$ for $c l f \mathrm{~A}$ and eta, respectively (Fig. 2).

\section{Prevalence of methicillin-resistant (mecA) gene of Staphylococcus aureus}

Detecting antimicrobial-resistant genes was carried out from the $100 \mathrm{~S}$. aureus isolates, regardless of antimicrobial susceptibility phenotypes. The results obtained are shown in Fig. 4. Methicillin resistance A $(m e c \mathrm{~A})$ gene was amplified from the isolates in any of the isolates in the present study. Out of the 100 isolates of S. aureus, $12 \%(12 / 100)$ of the isolates possessed the mecA gene and a large proportion of these isolates were obtained from Holeta $58.34 \%$ (7/12). None of the isolates from Adaberga possessed the methicillin-resistant (mecA) gene. Figure 4 shows a $1.5 \%$ agarose $(\mathrm{w} / \mathrm{v})$ gel depicting the mecA gene fragments that were amplified by PCR with the expected amplicon size (689 bp).

\section{Discussion}

Staphylococcus aureus is one of the major causes of mastitis that leads to a reduction of milk production in dairy cattle (Krishnamoorthy et al., 2017). The control of bovine mastitis is vital not only in Ethiopia but also in the world. Therefore, it is essential to investigate the pathogens using molecular techniques as vibrant components to control intra-mammary infections. In the dairy industry, mastitis can be reduced by identification of exact pathogenesis and virulent factors present in infectious microorganisms. The molecular typing of infectious

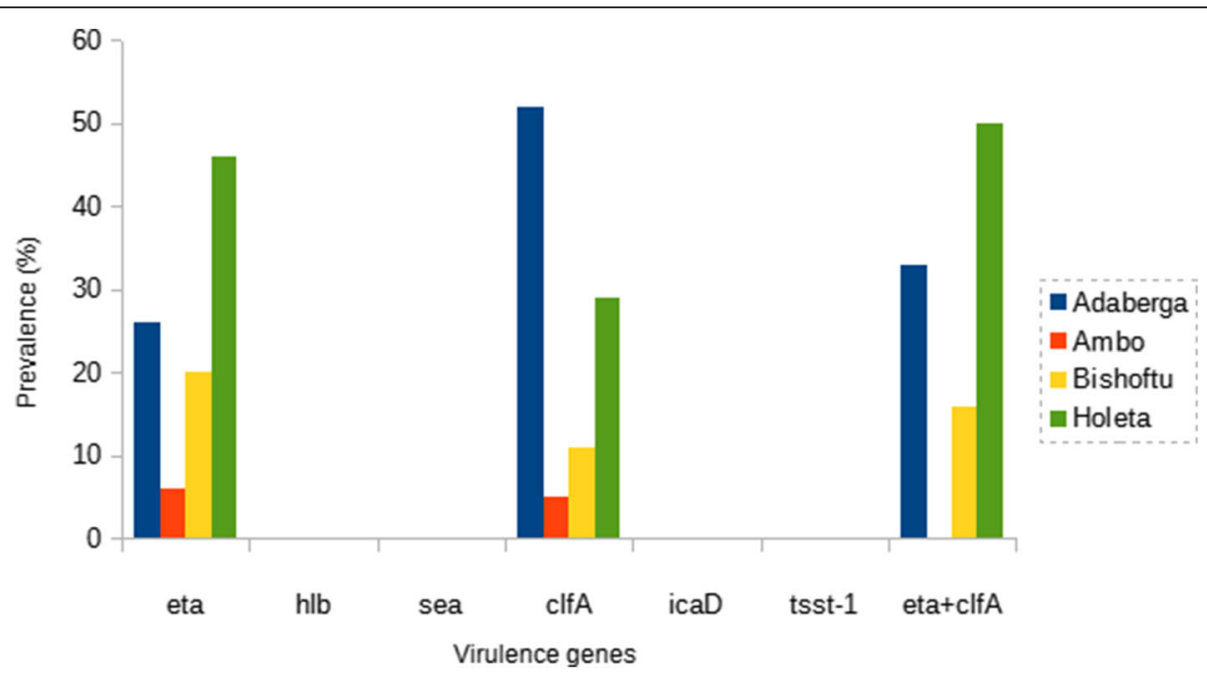

Fig. 3 Prevalence of virulence genes in S. aureus isolated from bovine subclinical mastitis 


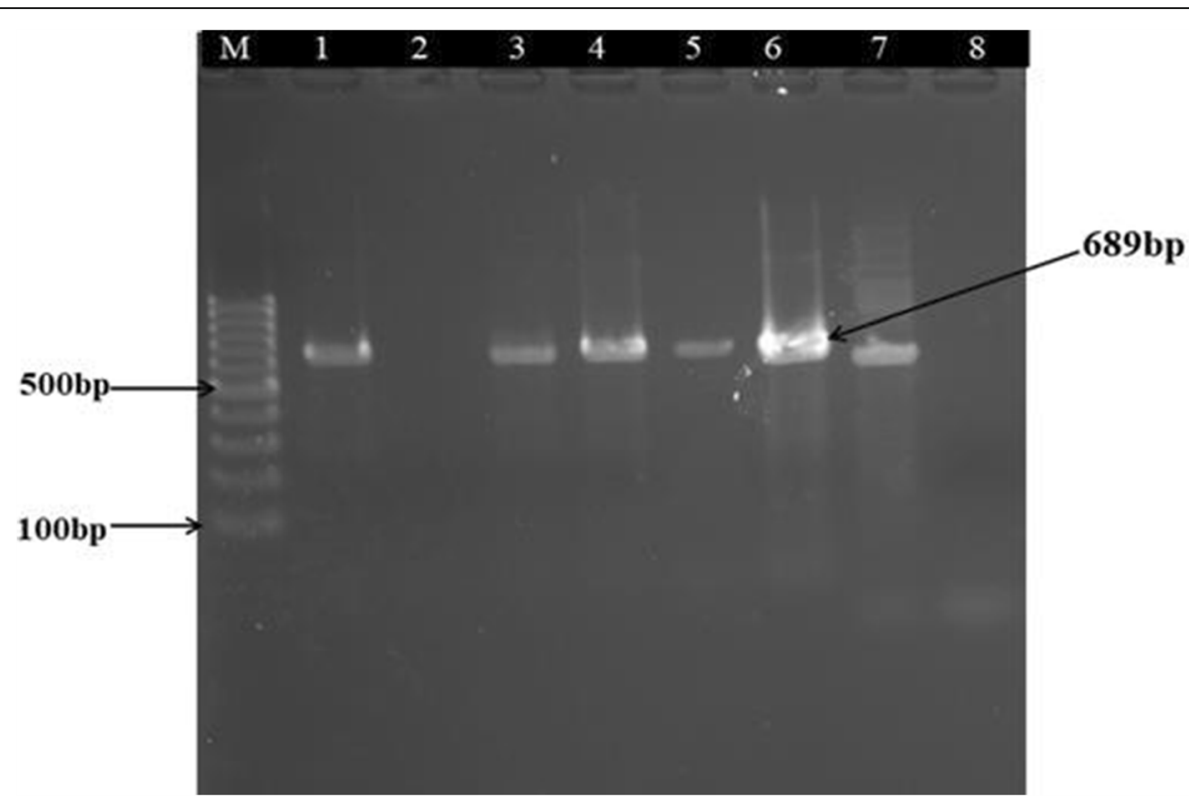

Fig. 4 Agarose gel electrophoresis analysis for the mecA gene in S. aureus isolates. Lane $M=100-b p$ DNA marker, lanes $1-7=$ test samples

agents is known to be an essential part of infection control strategies and is crucial to the track and spread of contagious infections from one region to others or among different herds. Consequently, it is crucial to examine the mastitis-causing bacteria using molecular methods as forceful tools to control IMI. Because S. aureus is the most commonly contagious mastitis pathogens worldwide, it is important to reveal virulence factors of these agents to develop effective control strategies against mastitis caused by this pathogen (Khan et al., 2013). In addition, an effective vaccine against IMI is not available; therefore, prevention and control of mastitis needs detection of the principal antigenic determinants for the strategy and progress of more proficient vaccines against mastitis-causing bacteria, especially $S$. aureus.

A number of studies have been conducted in Ethiopia on the prevalence of $S$. aureus in bovine milk (Abera et al., 2012; Mekonnen et al., 2017). Most of these researches focused on the importance of this pathogen as a cause of clinical and subclinical mastitis; however, its virulence determinants have not been well addressed. To our knowledge, there is no reliable information on molecular data of virulence genes in S. aureus from mastitic bovine milk samples in Ethiopia. Epidemiological studies indicate that $S$. aureus strain agents of milk produce a group of virulence factors and it is believed that there is a relationship between the severity of the infection and the virulence factors produced by $S$. aureus (Almaw et al., 2008). Hence, in this study, the prevalence of certain virulence genes such as sea, eta, $h l b, c l f \mathrm{~A}$, $i c a D$, and tsst-1 for $S$. aureus was evaluated.
In this study, from a total of 130 CMT-positive isolates, S. aureus was the most frequently encountered organism with an isolation rate of $76 \%$. The predominance and primary role of $S$. aureus isolate in bovine mastitis have also been reported in other studies (Abera et al., 2012; Demissie et al., 2018). Apart from Ethiopia, $S$. aureus has also been reported as the chief etiological agent of mastitis in cattle by many studies from African and Asian countries (Abebe et al., 2016). Though direct comparisons among studies might be difficult, but in general, the variation in the prevalence between the present and previous studies might be due to differences in detection methods, geographical location of the study sites, and differences in farm management practices in each studied farms. S. aureus is adapted to survive in the udder and usually establishes mild subclinical infection of long duration from which it is shed through milk serving as the source of infection for other healthy cows and transmitted during the milking process (Radostits et al., 2007). Hence, the organism has been assuming apposition of major importance as a cause of bovine mastitis.

Out of 100 phenotypically positive S. aureus isolates, $68 \%$ of them were confirmed S. aureus isolates by using PCR amplification. The finding of this study was in agreement with Li et al. (2018b). Regardless of the isolation and identification techniques employed, the confirmation of $S$. aureus in milk using molecular highlights the need for both strict farm management practices and proper sanitary procedures to be implemented during milking operations. 
The pathogenicity of $S$. aureus is closely related to the presence of various virulence genes (Kot et al., 2016). In this study, six virulence factors of the pathogen were screened but only two of them were positive based on PCR amplification. Our data showed that 15 out of $68 \mathrm{~S}$. aureus isolates carried exfoliative toxin A (eta) (22.05\%) and 17 out of $68 \mathrm{~S}$. aureus isolates contained clfA (25\%) genes. Of $68 \mathrm{~S}$. aureus examined, 32 (47.05\%) were positive for one or more virulence genes. About half $(52.95 \%)$ of the isolates did not contain any of the virulence genes tested. The eta and $c l f A$ were found at higher frequencies whereas sea, hlb, icaD, and tsst-1 were not found in all tested isolates. Five isolates harbored both eta and clfA genes. There has been no published information regarding clamping factor A (clfA) and exfoliative toxin A (eta) in the Ethiopian context. This is the first investigation regarding these genes in Ethiopia and there is no other work on these virulence factors. This finding is different from Srinivasan et al. (2006) who examined $78 \mathrm{~S}$. aureus isolates from the milk of cows with mastitis for 16 enterotoxin genes and found that $73(93.6 \%)$ of the isolates were positive for one or more enterotoxin genes from a similar area. However, Srinivasan et al. (2006) tested for 16 enterotoxin genes whereas in this study only one enterotoxin gene was tested. This might be the reason for the low prevalence of positive isolates in this study. The presence of the clumping factor gene is considered as Staphylococcus species virulence gene in the development and severity of mastitis in cows (Aarestrup et al., 1995). The above results suggested that $S$. aureus isolates with different genetic backgrounds have different abilities to acquire mobile genetic elements such as plasmids, phages, and pathogenicity islands.

\section{Conclusions}

The high prevalence of virulence genes (clfA and eta) in $S$. aureus bacteria was the most important finding of our study. All of the $S$. aureus bacteria harbored clfA and eta putative virulence factors which showed that they can be use as specific genetic markers for detection of pathogenic S. aureus bacteria in bovine subclinical mastitis cows. The presence of virulence factors in mastitiscausing Staphylococcus aureus is an alarming spot for veterinarians, as several sources are there for spreading of microorganisms to human being. The emergence of different antibiotic resistance and virulence in the last two decades is exerting a lot of pressure in the health sector. Detailed genomic evaluation of particular antibiotic-resistant strain with virulent factors may possess a great scope to develop a new disease control strategy.

\section{Abbreviations}

clfA: Clumping factor A; CMT: California mastitis test; DNA: Deoxyribonucleic acid; eta: Exfoliative toxin A; h/b: Beta hemolysin toxin; icaD: Intracellular adhesive toxin D; P-value: Predictive value; PCR: Polymerase chain reaction; Sea: Staphylococcal enterotoxin a; tsst-1: Toxic shock syndrome toxin one; $x^{2}$ : Pearson chi-square

\section{Acknowledgements}

The authors greatly appreciate the contribution made by the Ethiopian Institute of Agricultural Research, National Agricultural Biotechnology Research Center, in funding this project and the staff of the Animal Biotechnology Research Laboratory for assisting during the bench work which has led to the success of this study. We are thankful to the farmers and veterinarians who provided the milk samples used in this study.

\section{Authors' contributions}

The research idea and study design was developed by DTT. Sample collection were done by DTT, GM, HW and YEM. DTT supervised the study. DTT and YEM provided valuable information on data analysis and manuscript writing. All authors read and approved the fnal manuscript.

\section{Funding}

This study was supported by the Ethiopian Institute of Agricultural Research and Addis Ababa University. The institutions had no role in the design of the study; in the collection, analysis, and interpretation of the data; and in writing the manuscript.

\section{Availability of data and materials}

The datasets used and/or analyzed during the current study are available from the corresponding author on reasonable request.

\section{Declarations}

\section{Ethics approval and consent to participate}

This study was conducted after gaining full approval by the ethical review board of the College of Veterinary Medicine and Agriculture, Addis Ababa University, Ethiopia. Informed written consent was taken from all participants prior to participation in this study. Also, permission from dairy farm owners/ managers was obtained before the collection of milk samples.

\section{Consent for publication}

Not applicable

\section{Competing interests}

The authors declare that they have no competing interests.

\section{Author details}

${ }^{1}$ Animal Biotechnology Research Program, National Agricultural Biotechnology Research Center, Ethiopian Institute of Agricultural Research, P.O. Box: 249, Holeta, Ethiopia. ${ }^{2}$ Addis Ababa University, College of Veterinary Medicine and Agriculture, Department of Veterinary Microbiology,

Immunology and Public Health, P.O. Box: 34, Bishoftu, Ethiopia.

Received: 22 March 2021 Accepted: 24 June 2021

Published online: 13 July 2021

\section{References}

Aarestrup FM, Wegener H, Rosdahl V (1995) Evaluation of phenotypic and genotypic methods for epidemiological typing of Staphylococcus aureus isolates from bovine mastitis in Denmark. Vet Microbiol 45(2-3):139-150. https://doi.org/10.1016/0378-1135(95)00043-A

Abebe R, Hatiya H, Abera M, Megersa B, Asmare K (2016) Bovine mastitis: prevalence, risk factors and isolation of Staphylococcus aureus in dairy herds at Hawassa milk shed, South Ethiopia. BMC Vet Res 12(1):270. https://doi. org/10.1186/s12917-016-0905-3

Abera M, Demie B, Aragaw K, Regassa F, Regassa A (2010) Isolation and identification of Staphylococcus aureus from bovine mastitic milk and their drug resistance patterns in Adama town, Ethiopia. J Vet Med Anim Health 2: 29-34

Abera M, Habte T, Aragaw K, Asmare K, Sheferaw D (2012) Major causes of mastitis and associated risk factors in smallholder dairy farms in and around Hawassa, Southern Ethiopia. Trop Anim Health Prod 44(6):1175-1179. https:// doi.org/10.1007/s11250-011-0055-3 
Almaw G, Zerihun A, Asfaw Y (2008) Bovine mastitis and its association with selected risk factors in smallholder dairy farms in and around Bahir Dar, Ethiopia. Trop Anim Health Prod 40(6):427-432. https://doi.org/10.1007/s112 50-007-9115-0

Bhatt VD, Patel MS, Joshi CG, Kunjadia A (2011) Identification and antibiogram of microbes associated with bovine mastitis. Anim Biotechnol 22(3):163-169. https://doi.org/10.1080/10495398.2011.570132

Bobbo T, Ruegg P, Stocco G, Fiore E, Gianesella M, Morgante M, Pasotto D, Bittante G, Cecchinato A (2017) Associations between pathogen-specific cases of subclinical mastitis and milk yield, quality, protein composition, and cheese-making traits in dairy cows. J Dairy Sc 100(6):4868-4883. https://doi. org/10.3168/jds.2016-12353

Demissie TF, Menghistu HT, Mitiku MA (2018) Prevalence of mastitis and identification of its bacterial causative agents in small holder dairy farms in and around Wukro of Tigray region, Ethiopia. Int. J. Adv. Res. Biol. Sci 5:10-22

Diep BA, Otto M (2008) The role of virulence determinants in communityassociated MRSA pathogenesis. Trends Microbiol 16(8):361-369. https://doi. org/10.1016/j.tim.2008.05.002

Graveland H, Duim B, Van Duijkeren E, Heederik D, Wagenaar JA (2011) Livestockassociated methicillin-resistant Staphylococcus aureus in animals and humans. Int J Med Microbiol 301(8):630-634. https://doi.org/10.1016/j.jjmm.2 011.09 .004

Greco C, Mastronardi C, Pagotto F, Mack D, Ramirez-Arcos S (2008) Assessment of biofilm-forming ability of coagulase-negative staphylococci isolated from contaminated platelet preparations in Canada. Transfusion 48(5):969-977. https://doi.org/10.1111/j.1537-2995.2007.01631.x

Khan A, Hussain R, Javed MT, Mahmood F (2013) Molecular analysis of virulent genes (coa and spa) of Staphylococcus aureus involved in natural cases of bovine mastitis. Pak J Agric Sci 50:739-743

Kot B, Szweda P, Frankowska-Maciejewska A, Piechota M, Wolska K (2016) Virulence gene profiles in Staphylococcus aureus isolated from cows with subclinical mastitis in eastern Poland. J Dairy Res 83(2):228-235. https://doi. org/10.1017/S002202991600008X

Krishnamoorthy P, Suresh K, Saha S, Govindaraj G, Shome B, Roy P (2017). Metaanalysis of prevalence of subclinical and clinical mastitis, major mastitis pathogens in dairy cattle in India. Int J Curr Microbiol App Sci 6(3):1214-1234

Kumar JD, Negi YK, Gaur A, Khanna D (2009) Detection of virulence genes in Staphylococcus aureus isolated from paper currency. Int J Infect Dis 13(6): e450-e455. https://doi.org/10.1016/j.ijid.2009.02.020

Li X, Fang F, Zhao J, Lou N, Li C, Huang T, Li Y (2018a) Molecular characteristics and virulence gene profiles of Staphylococcus aureus causing bloodstream infection. Braz J Infect Dis 22(6):487-494. https://doi.org/10.1016/j.bjid.201 8.12 .001

Li X, Fang F, Zhao J, Lou N, Li C, Huang T, Li Y (2018b) Molecular characteristics and virulence gene profiles of Staphylococcus aureus causing bloodstream infection. Braz J Infect Dis 22(6):487-494. https://doi.org/10.1016/j.bjid.201 8.12 .001

Mehrotra M, Wang G, Johnson WM (2000) Multiplex PCR for detection of genes for Staphylococcus aureus enterotoxins, exfoliative toxins, toxic shock syndrome toxin 1, and methicillin resistance. J Clin Microbiol 38(3):10321035. https://doi.org/10.1128/JCM.38.3.1032-1035.2000

Mekonnen SA, Koop G, Melkie ST, Getahun CD, Hogeveen H, Lam TJ (2017) Prevalence of subclinical mastitis and associated risk factors at cow and herd level in dairy farms in North-West Ethiopia. Prev Vet Med 145:23-31. https:// doi.org/10.1016/j.prevetmed.2017.06.009

Oliver, S., Gonzalez, R., Hogan, J., Jayarao, B., Owens, W., 2004. Microbiological procedures for the diagnosis of bovine udder infection and determination of milk quality, Verona, WI, USA: the National Mastitis Council. Inc.[Google Scholar].

Ote I, Taminiau B, Duprez J-N, Dizier I, Mainil JG (2011) Genotypic characterization by polymerase chain reaction of Staphylococcus aureus isolates associated with bovine mastitis. Vet Microbiol 153(3-4):285-292. https://doi.org/10.1016/ j.vetmic.2011.05.042

Patel K, Joshi C, Kunjadiya A (2017) Isolation and molecular identification of Staphylococcus spp. from bovine mastitis milk samples. Int J Adv Res 5:23205407

Radostits OM, Gay C, Hinchcliff KW, Constable PD (2007) A textbook of the diseases of cattle, horses, sheep, pigs and goats. Vet Med 10:2045-2050

Riffon R, Sayasith K, Khalil H, Dubreuil P, Drolet M, Lagacé J (2001) Development of a rapid and sensitive test for identification of major pathogens in bovine mastitis by PCR. J Clin Microbiol 39(7):2584-2589. https://doi.org/10.1128/ JCM.39.7.2584-2589.2001

Rollin E, Dhuyvetter K, Overton M (2015) The cost of clinical mastitis in the first 30 days of lactation: an economic modeling tool. Prev Vet Med 122(3):257264. https://doi.org/10.1016/j.prevetmed.2015.11.006

Song X, Huang X, Xu H, Zhang C, Chen S, Liu F, Guan S, Zhang S, Zhu K, Wu C (2020) The prevalence of pathogens causing bovine mastitis and their associated risk factors in 15 large dairy farms in China: an observational study. Vet Microbiol 247:108757. https://doi.org/10.1016/j.vetmic.2020.108757

Srinivasan V, Sawant AA, Gillespie BE, Headrick SJ, Ceasaris L, Oliver SP (2006) Prevalence of enterotoxin and toxic shock syndrome toxin genes in Staphylococcus aureus isolated from milk of cows with mastitis. Foodbourne Pathog Dis 3(3):274-283. https://doi.org/10.1089/fpd.2006.3.274

Tesfaye GY, Regassa FG, Kelay B (2010) Milk yield and associated economic losses in quarters with subclinical mastitis due to Staphylococcus aureus in Ethiopian crossbred dairy cows. Trop Anim Health Prod 42(5):925-931. https://doi.org/10.1007/s11250-009-9509-2

van Leeuwen WB, Melles DC, Alaidan A, Al-Ahdal M, Boelens HA, Snijders SV, Wertheim H, van Duijkeren E, Peeters JK, van der Spek PJ (2005) Host- and tissue-specific pathogenic traits of Staphylococcus aureus. J Bacteriol 187(13): 4584-4591. https://doi.org/10.1128/JB.187.13.4584-4591.2005

Vaughn J, Abdi RD, Gillespie BE, Dego OK (2020) Genetic diversity and virulence characteristics of Staphylococcus aureus isolates from cases of bovine mastitis. Microb Pathog 144:104171. https://doi.org/10.1016/j.micpath.2020.1 04171

Yu F, Li T, Huang X, Xie J, Xu Y, Tu J, Qin Z, Parsons C, Wang J, Hu L (2012) Virulence gene profiling and molecular characterization of hospital-acquired Staphylococcus aureus isolates associated with bloodstream infection. Diagn Microbiol Infect Dis 74(4):363-368. https://doi.org/10.1016/j.diagmicrobio.2 012.08 .015

Zecconi A, Cesaris L, Liandris E, Daprà V, Piccinini R (2006) Role of several Staphylococcus aureus virulence factors on the inflammatory response in bovine mammary gland. Microb Pathog 40(4):177-183. https://doi.org/10.101 6/j.micpath.2006.01.001

\section{Publisher's Note}

Springer Nature remains neutral with regard to jurisdictional claims in published maps and institutional affiliations.

Ready to submit your research? Choose BMC and benefit from:

- fast, convenient online submission

- thorough peer review by experienced researchers in your field

- rapid publication on acceptance

- support for research data, including large and complex data types

- gold Open Access which fosters wider collaboration and increased citations

- maximum visibility for your research: over $100 \mathrm{M}$ website views per year

At $\mathrm{BMC}$, research is always in progress.

Learn more biomedcentral.com/submissions 